\title{
Magnetostratigraphy of the Campanian/Maastrichtian boundary succession from the Middle Vistula River section, central Poland
}

\author{
Tomasz PLASOTA ${ }^{1}$, Jerzy NAWROCKI ${ }^{2}$ and Ireneusz WALASZCZYK ${ }^{1, *}$ \\ 1 University of Warsaw, Institute of Geology, Żwirki i Wigury 93, 02-089 Warszawa, Poland \\ 2 Polish Geological Institute - National Research Institute, Rakowiecka 4, 00-975 Warszawa, Poland
}

Plasota, T., Nawrocki, J., Walaszczyk, I. 2015. Magnetostratigraphy of the Campanian/Maastrichtian boundary succession from the Middle Vistula River section, central Poland. Geological Quarterly, 59 (4): 831-842, doi: doi: 10.7306/gq.1262

\begin{abstract}
The magnetic polarities of the upper Upper Campanian-Lower Maastrichtian interval of the Middle Vistula River composite section (central Poland), were studied. Sixty-six hand-oriented samples for palaeomagnetic studies were taken from the sections of Raj, Raj North, Podole, Kłudzie and Dziurków. The inter-correlation between them is based primarily on bio-events. The sampled rocks generally revealed a very weak magnetic signal, however, quite reliable results were obtained. The whole interval studied, well constrained biostratigraphically, is referred to magnetostratigraphic chron C32n. The Campanian/Maastrichtian boundary, placed biostratigraphically in the upper part of the "Inoceramus" redbirdensis inoceramid Zone, is located near the top of the C $32 n 2 n$ Subchron. Thin reversed polarity intervals in the rocks correlated with the C $32 n 2 n$ chron most probably result from their partial remagnetisation (maghemitisation).
\end{abstract}

Key words: magnetostratigraphy, Campanian/Maastrichtian boundary, Poland.

\section{INTRODUCTION}

Due to endemism/provincialism (e.g., belemnites, ammonites) and diachroneity (e.g., ammonites, planktic foraminifera) of a number of biostratigraphic markers across the Campanian/Maastrichtian boundary (see e.g., Burnett, 1998; Christensen et al., 2000; Howe et al., 2003; Mutterlose et al., 2005; Ward et al., 2012; Peryt and Dubicka, 2015), there are problems with simple long-distance bio-correlation within this interval. The application of theoretically isochronous and potentially very effective methods, independent of available biostratigraphies, is thus of importance. Among the available tools currently used, magnetostratigraphy, besides chemostratigraphic methods, is available herein.

The Campanian-Maastrichtian succession of the Middle Vistula River composite section is extremely fossiliferous, yielding all stratigraphically relevant palaeontological macro- and micro-groups, which enable straightforward biostratigraphic correlation to the basal Maastrichtian stratotype section in Tercis, SW France. This gives a chance for a reliable biostratigraphic dating of the magnetostratigraphic signal, whose direct correlation is hampered by the lack of polarity inversions. The recorded magnetic signal in the Tercis section does not range to the base of the Maastrichtian (see Odin and

\footnotetext{
* Corresponding author, e-mail: i.walaszczyk@uw.edu.pl
}

Received: May 16, 2015; accepted: November 30, 2015; first published online: November 30, 2015
Lamaurelle, 2001; also Voigt et al., 2012: fig 3). This makes the Middle Vistula an important reference point to other sections, with good/excellent magnetostratigraphic scale, however, with limited biostratigraphic control (e.g., the Gubbio sections; Arthur and Fischer, 1977; Lowrie and Alvarez, 1981; Coccioni and Premoli Silva, 2015) or to those quite remote biogeographically (such as the Red Bird section, US Western Interior; see Gill and Cobban, 1966; Hicks and Obradovich, 1995 and literature therein; or the eastern North Pacific, see Ward et al., 2012).

This paper provides the magnetostratigraphy of the upper Upper Campanian through to basal Maastrichtian of the Middle Vistula section (central Poland; Fig 1), constrained by biostratigraphic methods (see Walaszczyk, 2012; Remin, 2012; Keutgen et al., 2012; Machalski, 2012; and also Peryt and Dubicka, 2015). The goal was the chronostratigraphic correlation of the studied Campanian-Maastrichtian interval. With the exception of a narrow interval across the Cretaceous-Danian boundary (Hansen et al., 1989), the magnetic properties of the Middle Vistula River succession, have never been published previously (although at least one attempt was announced by Hambach et al., 1995).

\section{GEOLOGICAL SETTING AND PREVIOUS STUDIES}

The Middle Vistula River valley composite section is located in south-central Poland, about $150 \mathrm{~km}$ SSE of Warsaw (Fig. 1). This composite section, consisting of a set of natural and artificial exposures along the Vistula River valley, exposes the Middle Albian-Danian succession, albeit with numerous observa- 

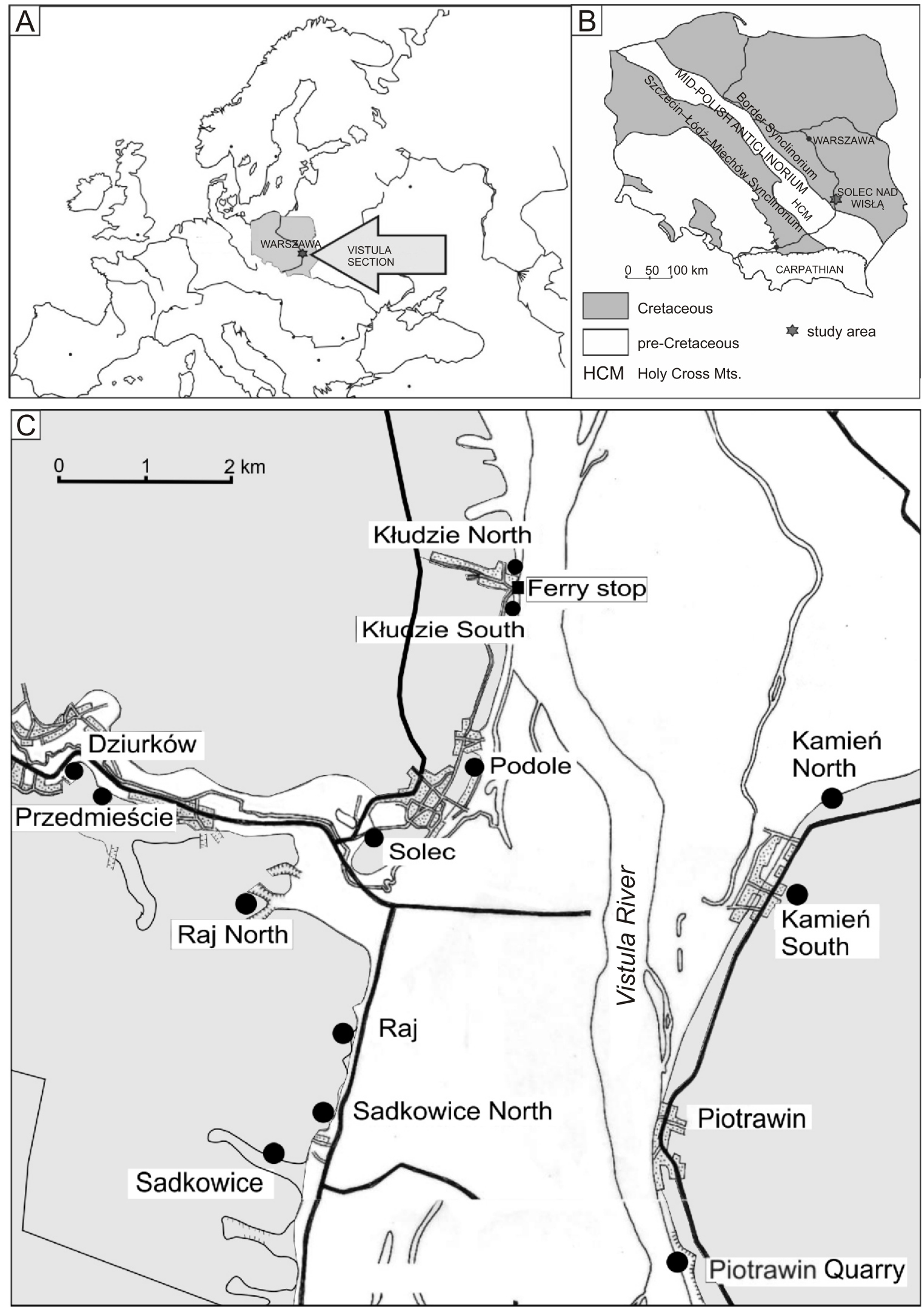

Fig. 1. Geological sketch-map of the investigated area (after Walaszczyk, 2004, 2012) 
tional gaps. The Campanian/Maastrichtian boundary interval is best exposed in the vicinity of the town of Solec, on the western bank of the river, between the villages of Pawłowice and Kłudzie North. The only good exposure on the eastern bank is a huge abandoned quarry south of the village of Piotrawin (Fig. 1). Structurally, the area of the Middle Vistula valley belongs to the southern wing of the Border Synclinorium, one of the main geological structure of extra-Carpathian Poland, trending NW-SE through the whole country (Pożaryski, 1974; Kutek, 2001; Żelaźniewicz et al., 2011). Consequently, the observed strata gently dip (5 to $10^{\circ}$ ) homoclinally to the NE (Pożaryski, 1948). With the exception of the basal Middle-Upper Albian part of the succession, the rest of the Cretaceous is represented by monotonous carbonate facies, dominated by siliceous marls (named opokas), rarely chalk (Pożaryski, 1948).

The first reliable report on its Upper Cretaceous succession and biostratigraphy was published by Pożaryski $(1938,1948)$. He subdivided the Campanian/Maastrichtian boundary interval studied herein into three successive units: $t, u$, and $v$, dated by him entirely as Maastrichtian (Fig. 2). These units show a mixed lithological-biostratigraphic character and, although useful in the early stages of the recognition, are no longer used. Subsequent studies of the boundary interval comprised macro- and microfossil groups, primarily those biostratigraphically meaningful (Fig. 2): ammonites (Błaszkiewicz, 1980; Machalski, 1996, 2012; Remin et al., 2015), belemnites (Kongiel, 1962; Remin, 2012, 2015; Keutgen et al., 2012), inoceramids (Walaszczyk, 2004), foraminifers (Pożaryska, 1954, Pożaryska and Peryt, 1979; Peryt, 1980, 2000; Peryt and Dubicka, 2015), and nannofossils (Gaździcka, 1978; Burnett et al., 1992). Also groups with little or poorly known biostratigraphic potential, but representing dominant elements of the record, were intensively studied; gastropod and bivalve molluscs (Abdel-Gawad, 1986) or sponges (Świerczewska-Gładysz, 2006, 2012). Kongiel (1962) raised the base of the Maastrichtian into the middle part of Pożaryski's unit $t$, corresponding to the lowest occurrence (FO) of the belemnite Belemnella (Belemnitella according to that author) lanceolata (Schlotheim), in agreement with the placement of the boundary at that time, as widely used in Boreal and Western Europe (Arkhangelsky, 1912; Jeletzky, 1951; see also Birkelund et al., 1984). This boundary placement was used since then, until the FO of the ammonite Pachydiscus neubergicus (Hauer) was accepted provisionally as the best basal Maastrichtian marker (Odin, 1996). Finally, the base of the Maastrichtian was raised up to around this level when the base of the stage was defined at a level calculated as an arithmetic mean of 12 bioevents as recognized in the Tercis quarry, the accepted stratotype section of the basal Maastrichtian boundary, which appeared to be slightly lower than the FO of $P$. neubergicus (Odin and Lamaurelle, 2001). In the Middle Vistula River section the new placement of the boundary was recognized based on inoceramid bivalves (Walaszczyk, 2004; see also Walaszczyk et al., 2002a, b) and ammonites (Machalski, 2012); the entire Pożaryski's units $t$ and $u$, and lower part of his unit $v$ were referred to the Maastrichtian. The belemnite and foraminiferal proxies of the boundary (after Remin, 2012; Keutgen et al., 2012; Peryt and Dubicka, 2015) are shown in Figure 2.

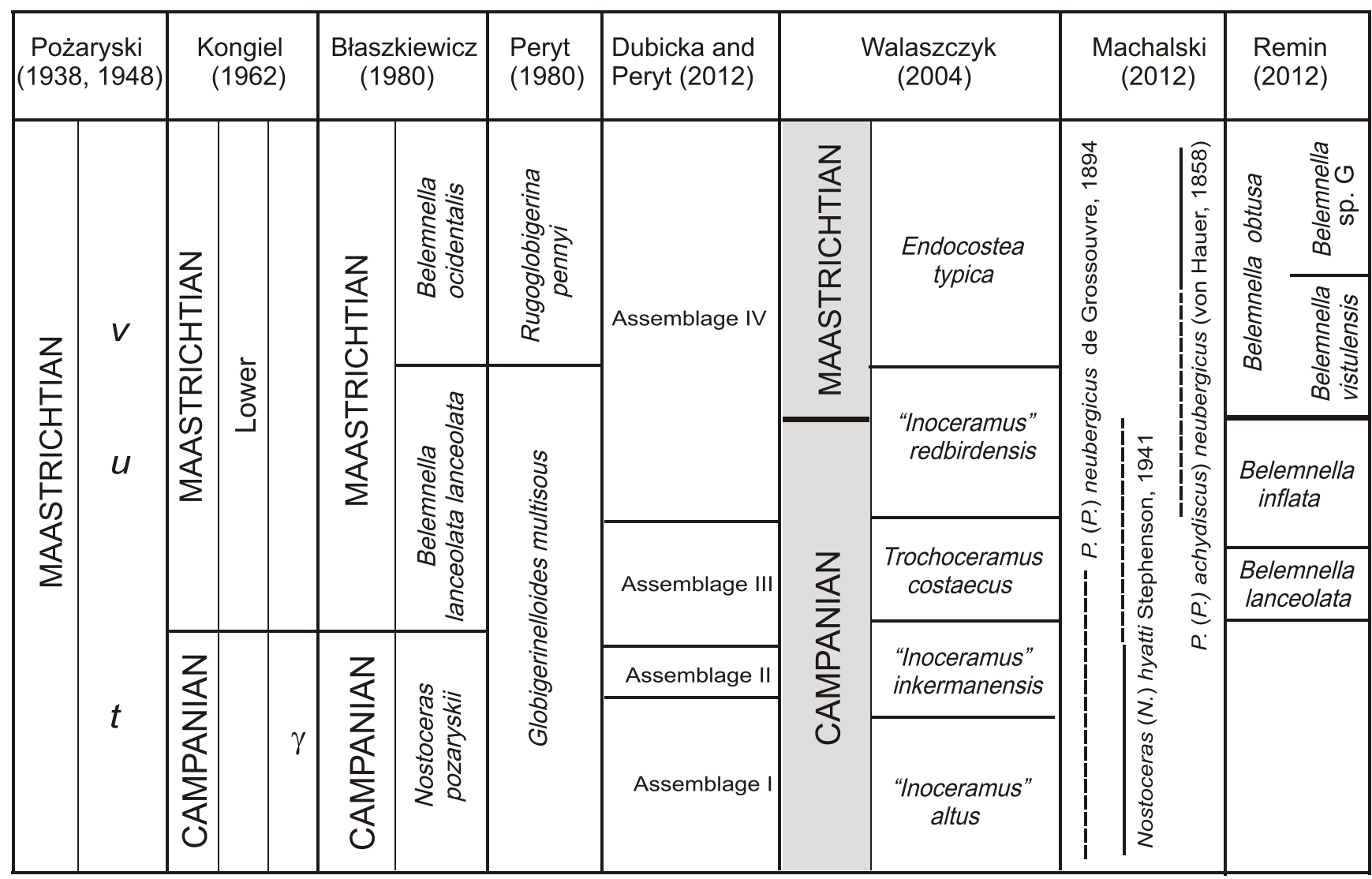

Fig. 2. Chronostratigraphy and biozonations, and vertical ranges of critical ammonite species (after various authors) of the uppermost Campanian and basal Maastrichtian of the Middle Vistula section 


\section{SAMPLING LOCATIONS}

Sixty-six hand-oriented samples for palaeomagnetic studies were taken from the sections of Raj, Raj North, Podole, Kłudzie and Dziurków (Fig. 1 and Table 1). The inter-correlation between them is based primarily on bio-events. Brief characteristics of the sampled localities in stratigraphic order are given below (see Fig. 1 for the geographic location); inoceramid biostratigraphy is after Walaszczyk (2004).

Raj. Small rural quarry located south of the village of Raj, in the northern wall of a little river valley flowing from the west into the main Vistula valley. $7 \mathrm{~m}$ of the succession, assigned to the "Inoceramus" inkermanensis Zone, are exposed.

Raj North. Small rural quarry, located about $500 \mathrm{~m}$ south-west of the main cross-road in the town of Solec. $12 \mathrm{~m}$ of the succession are exposed in the southern wall of the quarry, assigned to the Trochoceramus costaecus Zone and basal part of the "Inoceramus" redbirdensis Zone. The lowest occurrence of Belemnella lanceolata (Schlotheim), a belemnite marker of the base of the Maastrichtian in the traditional European definition of this boundary (see Błaszkiewicz, 1980; also Keutgen et al., 2012; Remin, 2012) is recognized in this quarry.

Podole. $15 \mathrm{~m}$ high wall in the western Vistula bank, close to the northern edge of the village of Podole, about 300 m north of the castle ruins in the town of Solec. The succession is assigned to the zones of Trochoceramus costaecus and "Inoceramus" redbirdensis.

Kłudzie South. The exposure is in the western bank of the Vistula River, south of the ferry river port in the village of Kłudzie. $18 \mathrm{~m}$ of the succession are exposed. There is a distinct marly horizon ("boundary marl", close to the Campanian/Maastrichtian boundary as defined by Walaszczyk, 2004), located in the middle part of the exposed succession. The succession belongs to the "Inoceramus" redbirdensis Zone and to the lower part of the Endocostea typica Zone.

Dziurków. Working rural quarry located at the eastern edge of the village of Dziurków, south of the road Solec-Lipsko. The quarry exposes $15 \mathrm{~m}$ of the succession of the Endocostea typica Zone.

Ta ble 1

Sampling statistics and GPS coordinates for particular localities

\begin{tabular}{|c|c|c|}
\hline Locality & $\begin{array}{l}\text { Number of hand samples and } \\
\text { specimens (in the brackets) for } \\
\text { palaeomagnetic studies }\end{array}$ & $\begin{array}{l}\text { GPS coordinates of } \\
\text { studied locality }\end{array}$ \\
\hline Raj & $13(27)$ & $\begin{array}{l}\text { N51 }{ }^{\circ} 6^{\prime} 51.8508^{\prime \prime} \\
\text { E21 } 45^{\prime} 18.7056^{\prime \prime}\end{array}$ \\
\hline Raj North & $13(32)$ & $\begin{array}{c}\text { N51 }{ }^{\circ} 7{ }^{\prime} 33.8268 " \\
\text { E21 }{ }^{\circ} 44^{\prime} 50.7048 "\end{array}$ \\
\hline Podole & $22(59)$ & $\begin{array}{l}\text { N51 }{ }^{\circ} 8^{\prime} 17.8656 " \\
\text { E21 }{ }^{\circ} 46^{\prime} 23.2284^{\prime \prime}\end{array}$ \\
\hline $\begin{array}{l}\text { Kłudzie } \\
\text { South }\end{array}$ & $15(41)$ & $\begin{array}{c}\text { N51ํ9'9.3564" } \\
\text { E21 }{ }^{\circ} 46^{\prime} 43.6764 "\end{array}$ \\
\hline Dziurków & $13(36)$ & $\begin{array}{c}\text { N51 }{ }^{\circ} 8^{\prime} 17.97^{\prime \prime} \\
\text { E21 }{ }^{\circ} 42^{\prime} 54.1296 "\end{array}$ \\
\hline
\end{tabular}

\section{LABORATORY METHODS}

Palaeomagnetic samples were hand-sampled and oriented with trend and plunge and taken manually off the solid rock. They were cut in the laboratory to one inch diameter cylindrical specimens (no less than two specimens from each sample) and subsequently thermally demagnetised. The intensity of natural remanent magnetisation (NRM) was measured on JR6A spinner magnetometer, and magnetic susceptilibity with a kappa bridge $\mathrm{KLY}-2$. Specimens were heated to $450^{\circ} \mathrm{C}$ with the following steps: $100,150,200,250,300,325,350,380,400$, 425 and $450^{\circ} \mathrm{C}$. Further demagnetisation was not effective because the intensities of remanent magnetisation were below the sensitivity of the magnetometer. Magnetic susceptilibity changes were monitored after each step of demagnetisation. The obtained data were computed statistically on Remasoft computer software (Chadima and Hrouda, 2006), which produced declination and inclination values for every demagnetisation step and mean magnetic directions. The results of demagnetisation were evaluated according to the least square line-fit method as described by Kirschvink (1980). Lowrie's test (Lowrie, 1990) was applied in order to determine the nature of magnetic carriers. For this purpose ten samples from the Dziurków and Podole sections were selected. All studies were performed in the Paleomagnetic Laboratory of the Polish Geological Institute - NRI.

\section{RESULTS}

\section{MAGNETIC CARRIERS}

The isothermal remanent magnetisation (IRM) experiment and subsequent demagnetisation of samples magnetised in three perpendicular directions according to the Lowrie test (Lowrie, 1990) indicate the predominance of two phases of low to medium coercivity magnetic carriers. One of them gives a significant drop of IRM at temperatures up to ca. $450^{\circ} \mathrm{C}$, and another has unblocking temperatures between 550 and $600^{\circ} \mathrm{C}$ (Fig. 3). Such properties point to the presence of maghemite and magnetite in the studied rocks (e.g., Dunlop and Özdemir, 1997). It should be noted, however, that the low coercivity carrier of IRM does not demagnetise completely even at a temperature of $600^{\circ} \mathrm{C}$. Most probably it is because the oxidation of maghemite during the heating in air conditions that leads to the production of hematite with unblocking temperatures $>600^{\circ} \mathrm{C}$ that is not primary, being not detected during acquisition of IRM. It cannot be excluded that a significant drop of IRM at temperatures $<500^{\circ} \mathrm{C}$ can be partly linked also with the presence of titanium-rich magnetite.

DEMAGNETISATION RESULTS PALAEOMAGNETIC COMPONENTS AND PALAEOPOLE

Almost all samples show weak natural remnant magnetisation (NRM). The intensities of NRM lie between 0.17 and $1.65 \times 10^{-4} \mathrm{~A} / \mathrm{m}$, with mean a value of about $0.8 \times 10^{-4} \mathrm{~A} / \mathrm{m}$. This fact and mineralogical changes during subsequent heating re- 

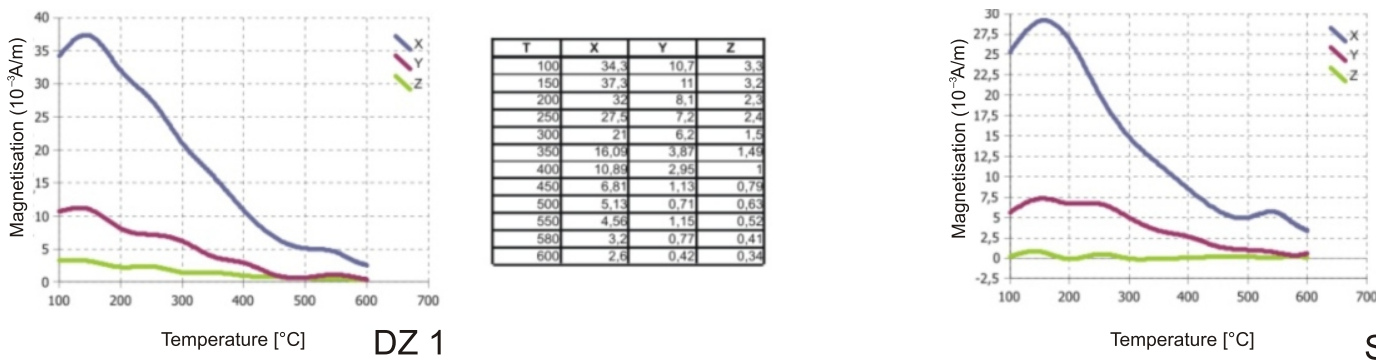

Temperature $\left[{ }^{\circ} \mathrm{C}\right]$

\section{SN 7}
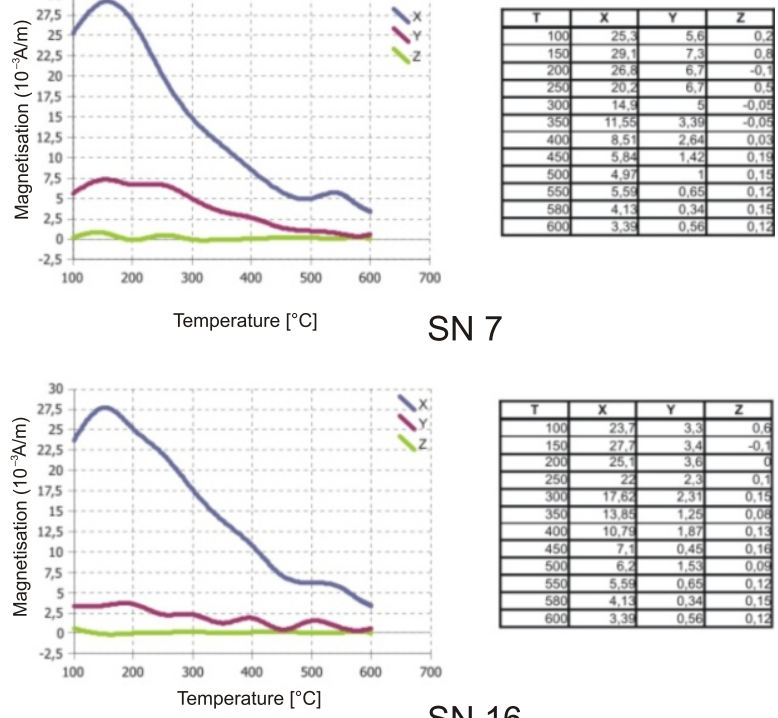

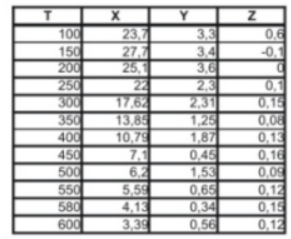

SN 16
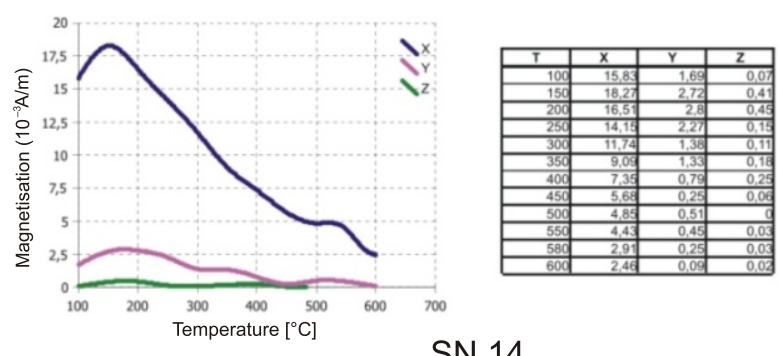

SN 14

DZ 9
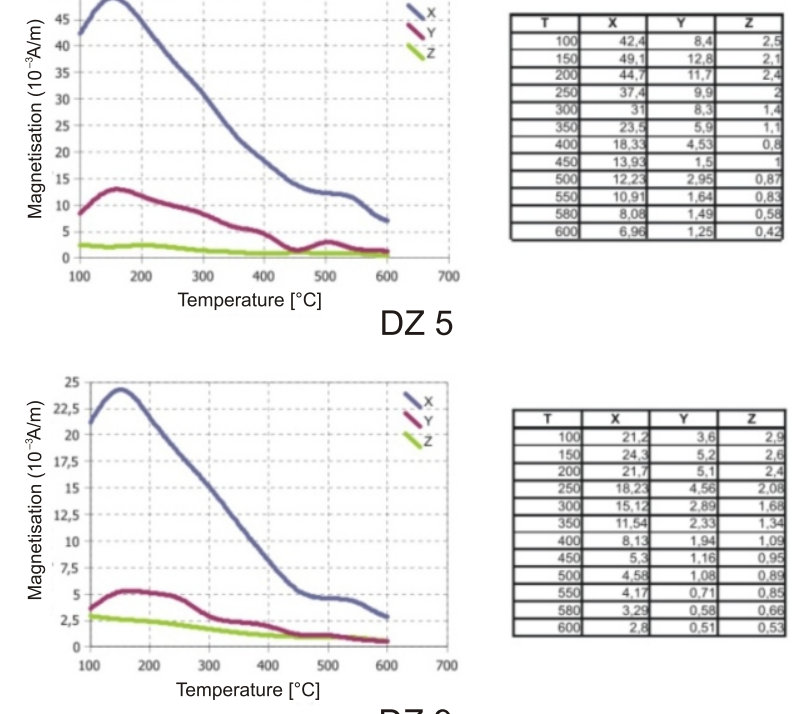

DZ 5

Fig. 3. Thermal demagnetisation of selected samples in artificial magnetic field (so called three axies experiment; Lowrie, 1990) sulted in 12 samples a very unstable demagnetisation path in 12 samples. Fortunately other samples enabled the characteristic remnant magnetisation (ChRM) to be defined in at least two specimens. The Late Cretaceous geomagnetic field in the study area, being a part of stable Europe, should provide a characteristic direction with declination oriented approximately $\mathrm{N}-\mathrm{S}$ and inclination close to ca. $60^{\circ}$ (see e.g., Besse and Curtillot, 2003). Well-defined characteristic components of reversed or normal polarity correspond to a wide spectrum of unblocking temperatures. The biggest drops of the NRM intensities can be observed at $100-200^{\circ} \mathrm{C}$ and $350-450^{\circ} \mathrm{C}$ (Fig. 4). It should be stressed, however, that these two temperature intervals do not allow two separate components of the NRM to be distinguished. The low and medium temperature directions have the same polarities and their spatial separation is impossible. It is likely that these magnetisations were acquired during the same geomagnetic polarity interval, close to each other in time. Because of the low initial values of the NRM most of the samples were not completely demagnetised and it is very likely that magnetite documented by the IRM demagnetisation curves (Fig. 3), carries also the ChRMs. In some samples the characteristic components were not sufficiently stable for their determination by the line-fit method (Fig. 5, samples: SN 7A and SN 10A). In this case, the direction defining the polarity was calculated as the mean from at least three steps of demagnetisation. Eleven samples revealed the presence of anomalous characteristic directions with deviated values of inclination or declination (Fig. 5, samples: SN 9A and SN 6A; Fig. 6). In spite of partial demagnetisation, these directions can be still resultant in origin i.e. containing an admixture of component with opposite polarity. This fact indicates that the rocks studied can also contain secondary components of magnetisation. These could be linked with maghemite formed due to the oxidation of magnetite grains after their sedimentation.

Only a few good quality ChRM directions defined by the line-fit method were obtained. Most of them were obtained from the Dziurków and Podole localities. Because of this, the mean palaeomagnetic direction and the palaeopole were calculated only for these localities (Fig. 7). The reversed polarity directions with negative inclinations are located in the opposite part of the hemisphere from the normal polarity ones. With a calculated critical angle $\gamma_{c}=10.12$ and an observed angle $\gamma=2.07$ they evidently pass the reversal test (McFadden and McElhinny, 1990). Directions defined on sample statistical level group relatively well, with the result that the palaeomagnetic pole lies at a latitude of $78^{\circ} \mathrm{N}$ and a longitude of $173^{\circ} \mathrm{E}$. This palaeopolar position was compared with the apparent polar wander path characteristic for stable Europe (Besse and Courtillot, 2003). It fits well to the Late Cretaceous segment of this path.

\section{MAGNETIC POLARITIES}

The normal and reversed polarity directions are grouped sequentially in normal and reversed polarity zones. Mixed polarity zones are documented in the sections of Kłudzie and Raj North. 

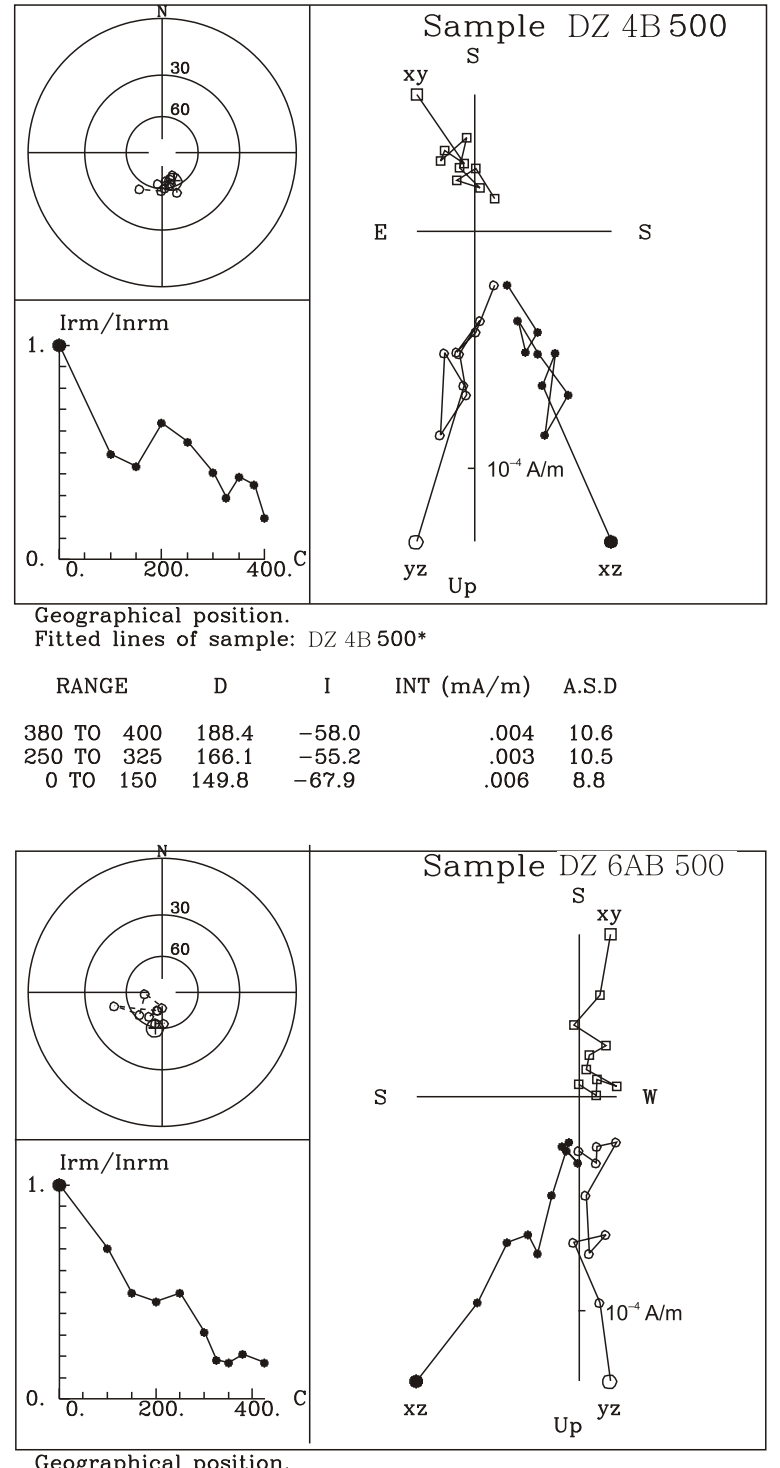

Geographical position.

Fitted lines of sample: DZ 6AB 500

$\begin{array}{lll}\text { RANGE } & D & \text { I } \\ \text { INT }(\mathrm{mA} / \mathrm{m}) & \text { A.S.D }\end{array}$

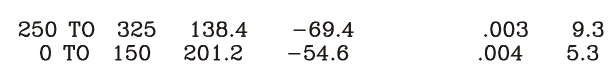

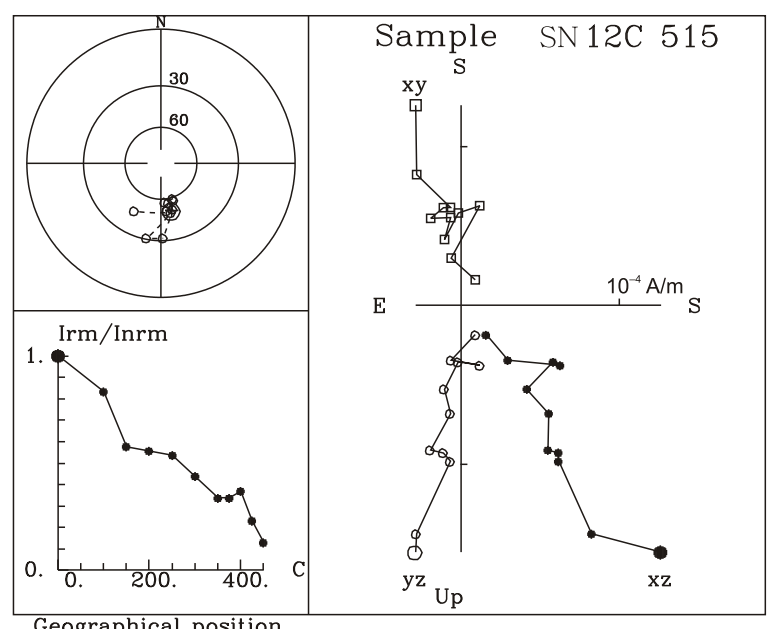

Geographical position.

Fitted lines of sample: SN $12 \mathrm{C} 515$

RANGE D I INT $(\mathrm{mA} / \mathrm{m})$ A.S.D

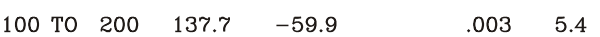

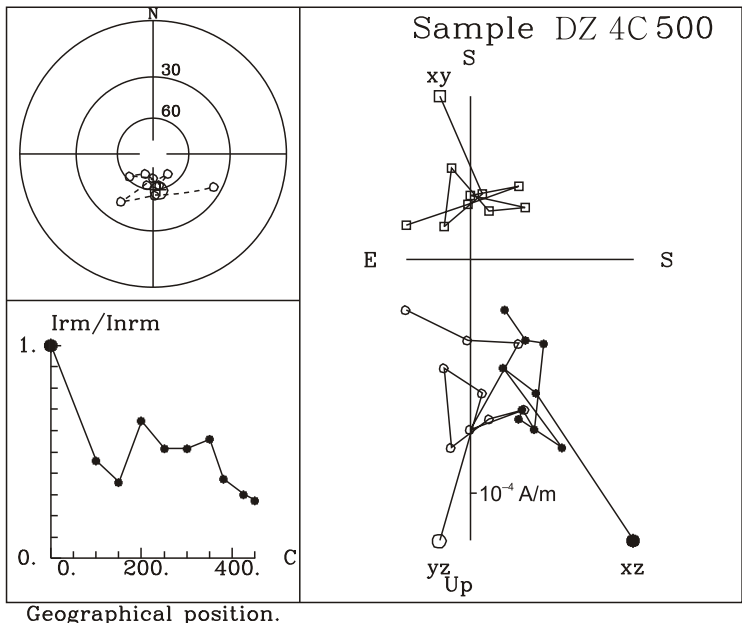

Geographical position.

Fitted lines of sample: DZ 4C 500

$\begin{array}{rccccr}\text { RANGE } & \text { D } & \text { I } & \text { INT }(\mathrm{mA} / \mathrm{m}) & \text { A.S.D } \\ \text { 380 TO } & 450 & 250.9 & -16.0 & .003 & 6.3 \\ \text { 0 TO } & 150 & 171.3 & -53.7 & .005 & 10.7\end{array}$

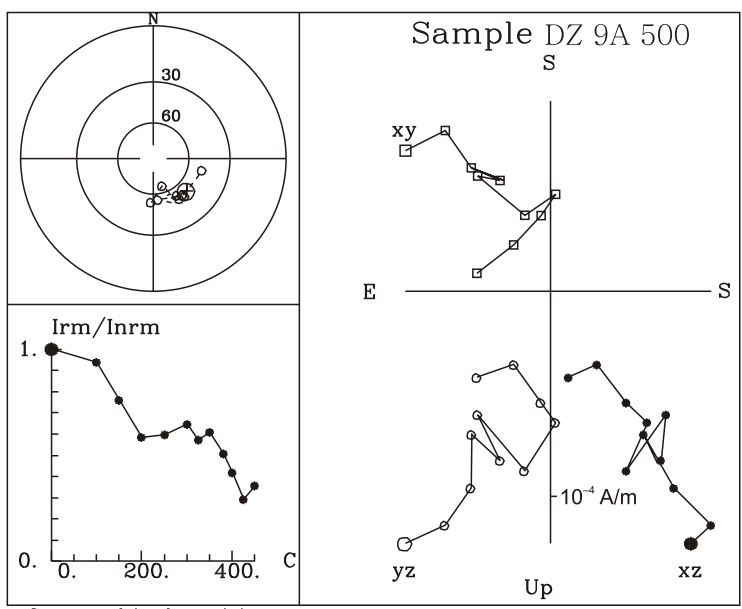

Geographical position.

Fitted lines of sample: DZ 9A 500

$\begin{array}{lll}\text { RANGE } & \text { D } & \text { I } \\ & \text { INT }(\mathrm{mA} / \mathrm{m}) \text { A.S.D }\end{array}$

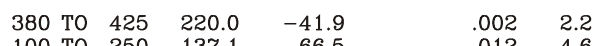

100 T0 $250 \quad 137.1 \quad-66.5$

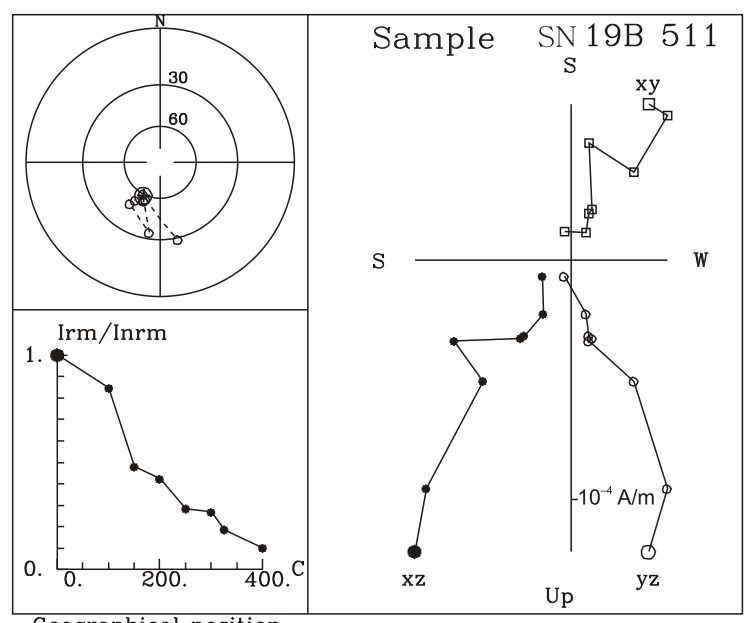

Geographical position.

Fitted lines of sample: SN 19B 511

RANGE D I INT $(\mathrm{mA} / \mathrm{m})$ A.S.D

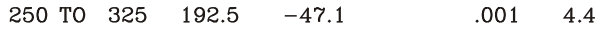

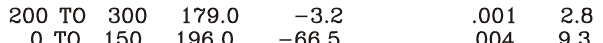



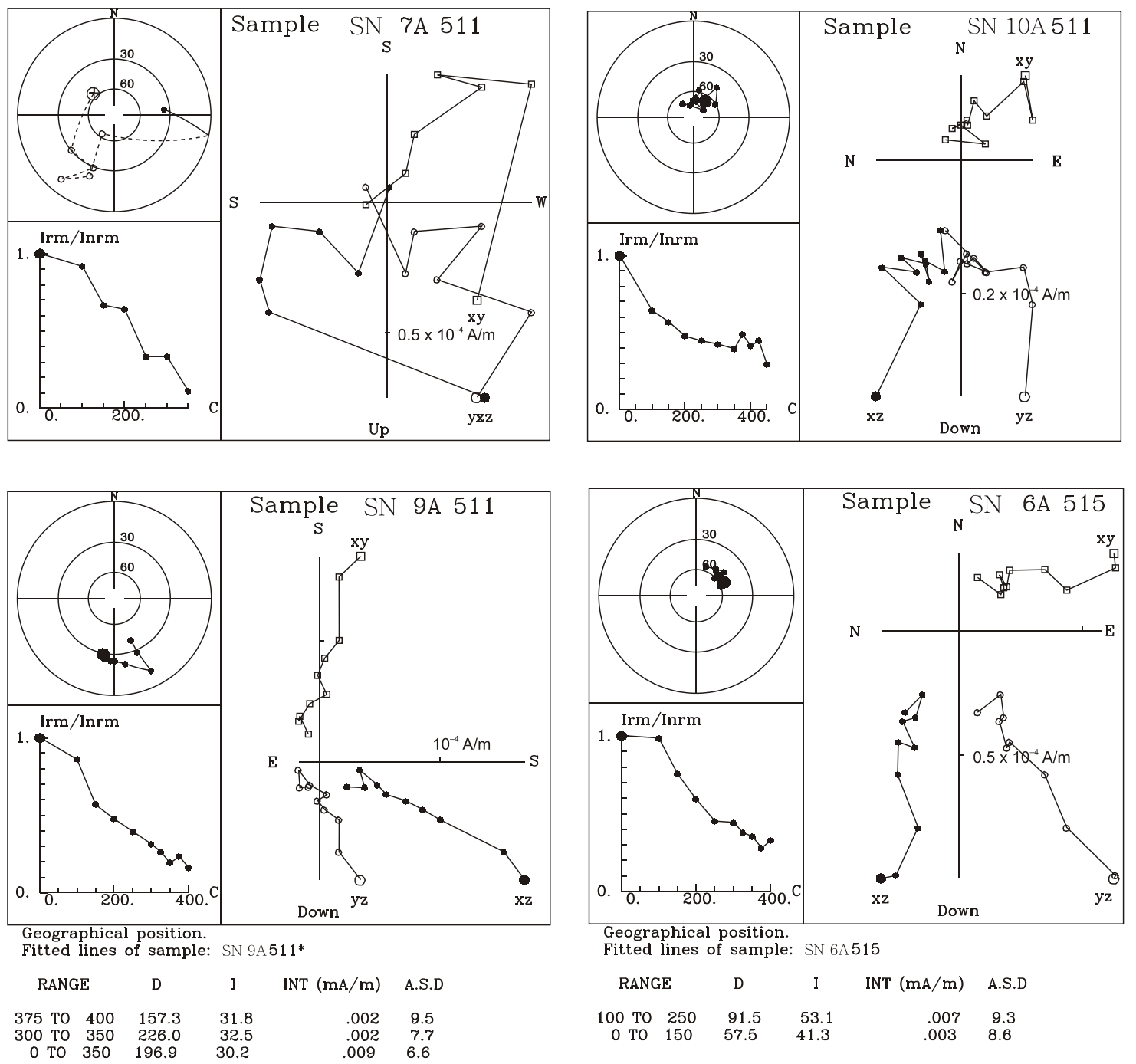

Fig. 5. Examples of thermal demagnetisation of samples from the Podole section with oscillating palaeomagnetic direction (samples SN 7A, SN 10A) and providing characteristic directions deviated from the expected locations (samples SN 9A, SN 6A)

Explanations as in Figure 4

Fig. 4. Examples of thermal demagnetisation of palaeomagnetic samples from the Dziurków (samples DZ 4B, DZ 4C, DZ 6AB, DZ 9A) and Podole (samples SN 12C, SN 19B) sections that provided a good quality data i.e. characteristic directions defined by the line-fit method (stereographic plot of palaeomagnetic directions during demagnetisation (left-upper figure), orthogonal plot (right figure) and intensity decay curve (left down figure)

Circles in the orthogonal plots represent vertical projections, squares represent horizontal projections; Irm - intensity of remanent magnetisation, Inrm - initial intensity of natural remanent magnetisation; the diagrams were prepared by the means of computer package written by Lewandowski et al. (1997); in the table presented below the diagrams the line-fit directions are listed (D - declination, I - inclination, INT drop of NRM intensity related to particular line-fit direction, A.S.D - angular standard deviation, RANGE - temperature interval for which particular line-fit direction was calculated) 

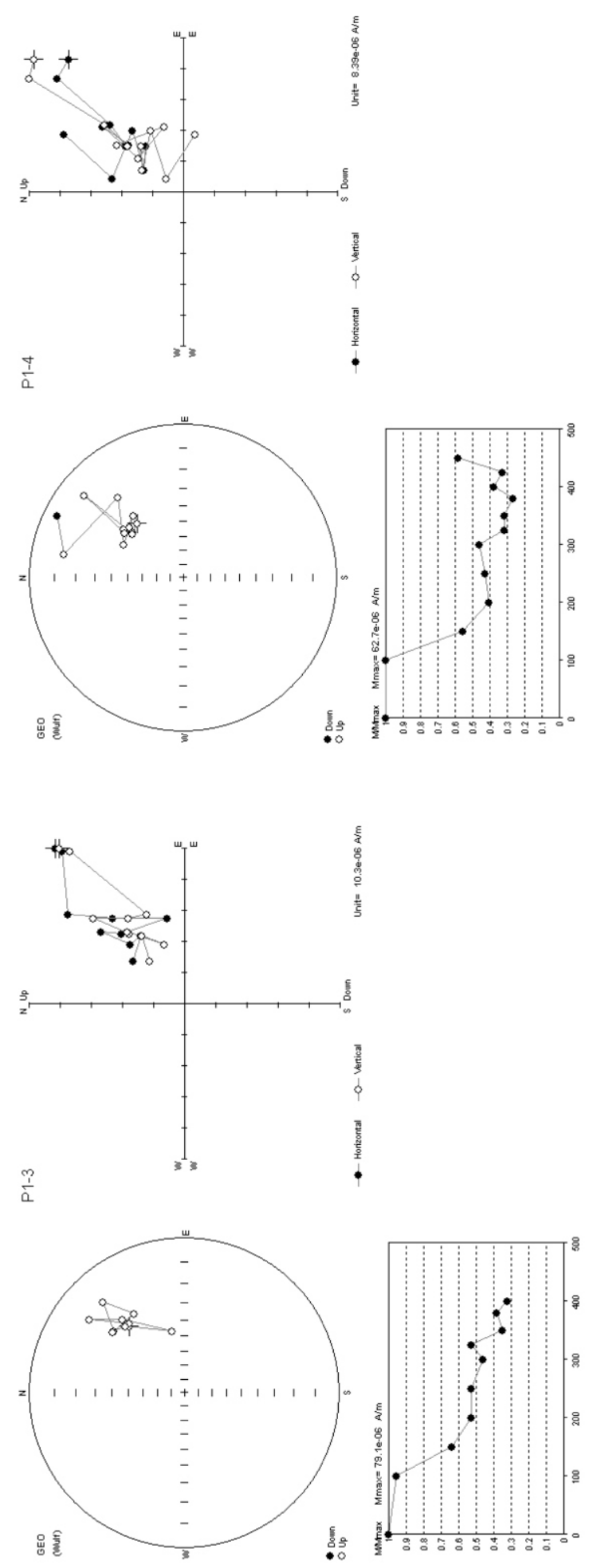
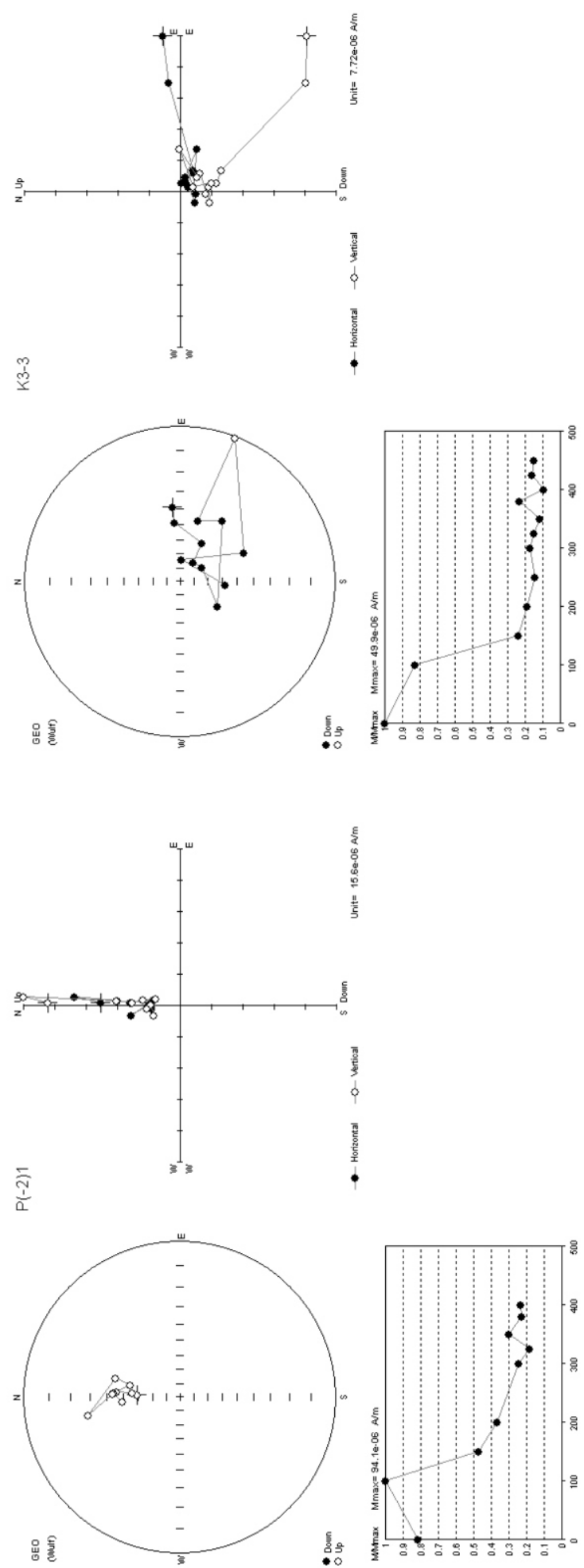

s.

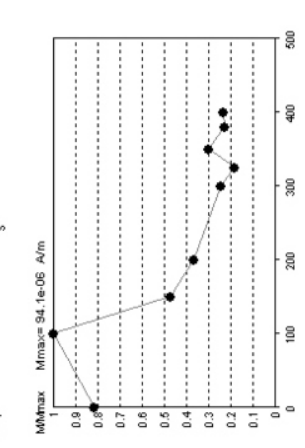

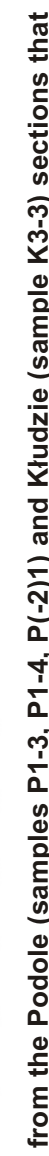

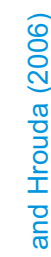

定

至

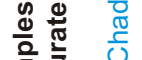

密

응

$\therefore \stackrel{2}{\circ}$

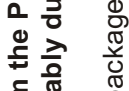

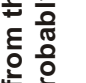

흔 힌

응 항 


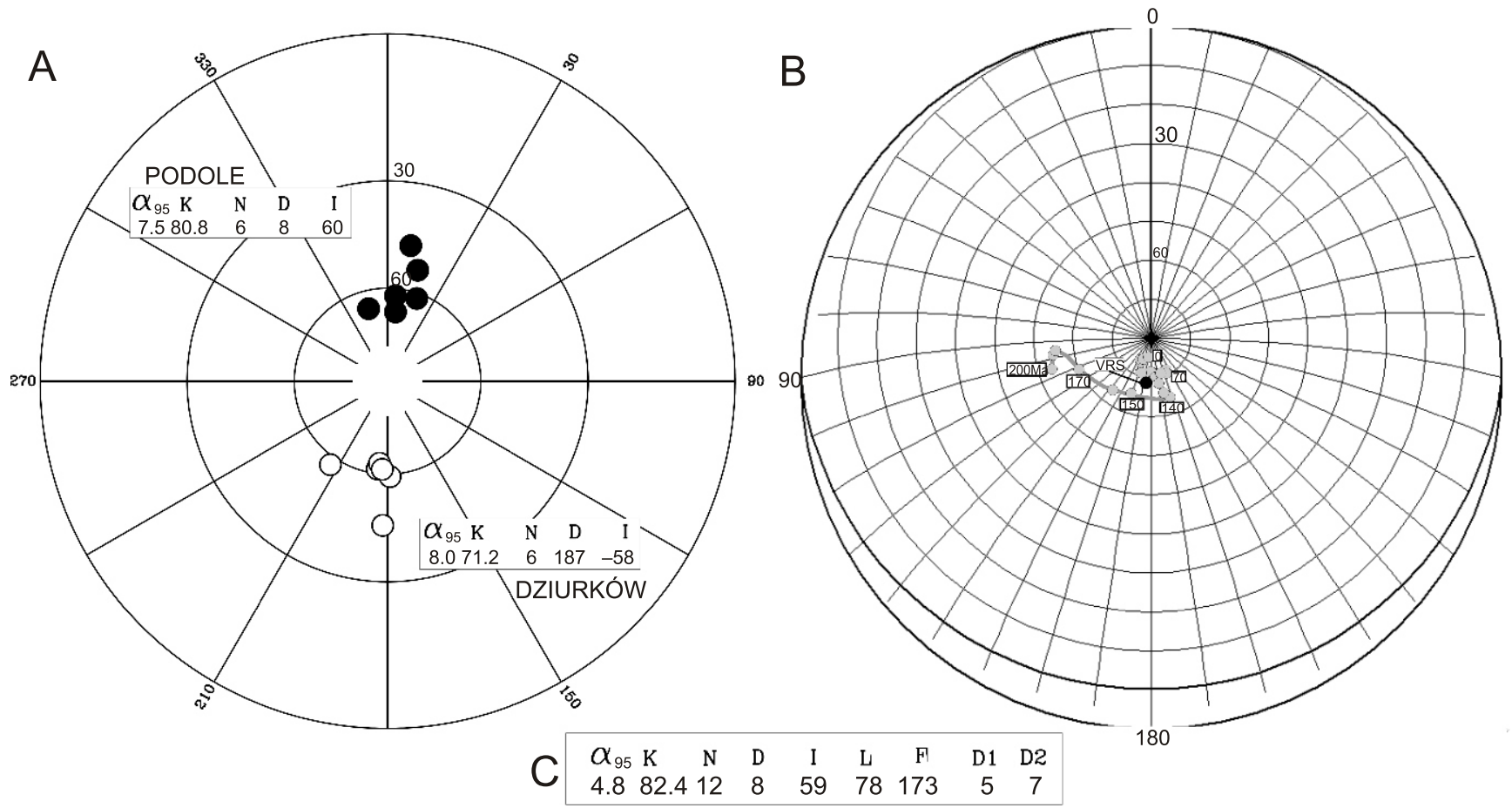

Fig. 7A - stereographic projection of palaeomagnetic directions calculated for the best quality samples from the Dziurków and Podole sections with their summary statistics; B-palaeopole calculated for the same sample set plotted as the black circle (named VRS) on the background of the apparent polar wander path (APWP) characteristic for stable Europe (Besse and Courtillot, 2003); C - summary statistics for the best quality samples from Dziurków and Podole

$\alpha_{95}$ - semi-angle of $95 \%$ confidence, $\mathrm{K}$ - precision parameter, $\mathrm{N}$ - number of samples, $\mathrm{D}$ - mean declination, I - mean inclination, $\mathrm{L}-$ latitude of palaeopole, F - longitude of palaeopole, D1 - error of the distance between site and palaeopole, D2 - palaeodeclination error

Samples from the Dziurków, Kłudzie and Raj sections were magnetised homogeneously in the reversed or normal polarity direction (Fig. 8). Uncertain polarities were connected with the unstable and resultant directions. The reversed polarity zones postulated in the middle part of the Podole section and the lowermost part of the Raj North section were drawn with a question mark because they are based on single samples with still shallower (between -20 and $-30^{\circ}$ ) than expected values of inclinations. The thick normal polarity zone defined in the synthetic magnetostratigraphic column according to data from the Podole and Raj North sections is not continuous. In fact, it was broken three times by reversed polarities. It should be stressed, however, that only the reversed zone from the topmost part of the Podole section is based on fully reversed directions isolated in more than one sample. Because of this, it is not drawn with question mark.

\section{DISCUSSION}

Magnetostratigraphic study was undertaken for the interval represented by the Raj, Raj North, Podole, Kłudzie and Dziurków sections, which span the topmost Campanian (inoceramid bivalve zones of "Inoceramus" inkermanensis; "I." costaecus and "I." redbirdensis (lower two-third of the zone), and the basal Lower Maastrichtian (the top third of the "I." redbirdensis Zone, and the zone of Endocostea typica; see
Figs. 2 and 8). Reference is made below to the recently published scale by Ogg and Hinnov (2012). A normal polarity record from the Kłudzie section falls into the "Inoceramus" redbirdensis Zone and the basal part of the Endocostea typica Zone and, based on the global magnetostratigraphic scale, it is attributed to subchron $\mathrm{C} 32 \mathrm{n} 2 \mathrm{n}$. Such constraints lead to the conclusion that all outcrops apart from Dziurków are coeval with subchron $\mathrm{C} 32 \mathrm{n} 2$. Thin reversed polarity intervals noted in the Podole and Raj North sections could represent cryptochrons that have not been recognized before this study. However, it is difficult to accept this interpretation because this part of the GPTS is based on good quality, densely-spaced data (see Ogg and Hinnov, 2012). More likely these thin reversed polarity intervals could result from partial remagnetisation of the studied rocks caused by late maghemitisation of magnetite grains. It should be stressed, however, that Lerbekmo and Braman (2002) published magnetostratigraphic data from Canada (Alberta) with three short reversed polarity zones inside subchron $\mathrm{C} 32 \mathrm{n} 2 \mathrm{n}$. Further palaeo- and petromagnetic studies are necessary to resolve this problem.

The reversed polarity record from the Dziurków section falls into the Endocostea typica Zone, so it was assumed to be a part of chron C32n1r (Fig. 8). Its correlation with the subchron C31r is not probable. Inoceramids characterizing the Dziurków succession are typical of the lower half of the E. typica Zone; its upper part, characterized by "Inoceramus" incurvus (or referred to this zone; see Walaszczyk et al., 2001; see also Ogg and 


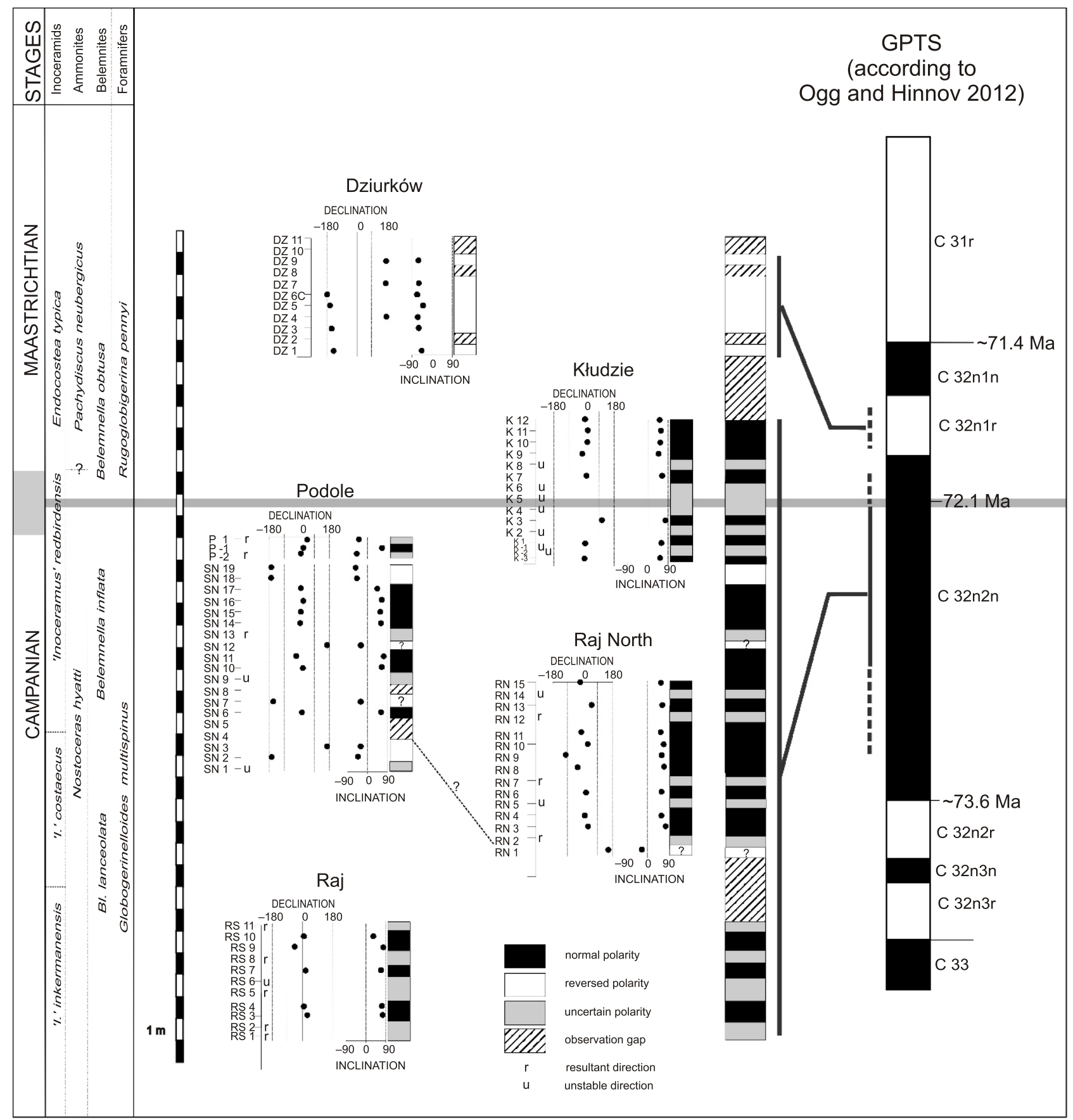

Fig. 8. Magnetostratigraphy of the Dziurków, Kłudzie, Podole, Raj and Raj North sections and their correlation with the global magnetostratigraphic (scale after Ogg and Hinnov, 2012); biostratigraphy after Walaszczyk (2004; inoceramids); Machalski (2012; ammonites); Remin (2012; belemnites); Peryt (1980; foraminifers)

Hinnov, 2012: fig. 27.6), is not represented. Simple correlation with the GPTS of magnetozones from Raj and Raj North sections could lead to the conclusion that these rocks were deposited during chron C33. This is not possible as all the biostratigraphic evidence show this part of the succession to be of latest Campanian (see Figs. 2 and 8). The normal polarity record from the Raj section corresponds to normal subchron $\mathrm{C} 32 \mathrm{n} 2 \mathrm{n}$. The remaining normal polarity intervals from the
Podole and Raj North sections belong to the "Inoceramus" redbirdensis and "Inoceramus" costaecus zones respectively. Both magnetic polarity records were also attributed to normal chron $\mathrm{C} 32 \mathrm{n} 2 \mathrm{n}$. Accordingly to our magnetostratigraphic correlation, the Maastrichtian/Campanian boundary is probably located in the middle part of the Kłudzie section, in the upper part of normal polarity subchron $\mathrm{C} 32 \mathrm{n} 2 \mathrm{n}$. 


\section{CONCLUSIONS}

1. Cretaceous rocks from the Middle Vistula River valley are useful for magnetostratigraphic studies despite their weak intensity magnetisation and a partial late remagnetisation that most probably results from maghemitisation of magnetite grains; further palaeo- and petromagnetic studies are necessary.

2. The biostratigraphically constrained Campanian/Maastrichtian boundary, placed in the studied succession close to the FO of the inoceramid bivalve Endocostea typica (Whitfield), and the ammonite, Pachydiscus neubergicus (Hauer) FAD, is located in the upper part of the normal polarity subchron C $32 n 2 n$. The stratigraphically youngest Dziurków section, as- signed to the Endocostea typica inoceramid Zone should be placed in the reversed polarity subchron C32n1r.

3 . Fine reversed polarity intervals are noted in the Podole and Raj North sections. They could result from partial and selective remagnetisation of the studied rocks due to late maghemitisation.

Acknowledgements. I. Walaszczyk acknowledges the financial support of the Faculty of Geology of the University of Warsaw (BST grant No. 173502). We are grateful for helpful reviews from J. Grabowski, S. Satolli and an anonymous reviewer, as well as for linguistic improvement of the final version by Ch.J. Wood.

\section{REFERENCES}

Abdel-Gawad, G.I., 1986. Maastrichtian non-cephalopod mollusks (Scaphopoda, Gastropoda and Bivalvia) of the Middle Vistula Valley, Central Poland. Acta Geologica Polonica, 36: 69-224.

Arkhangelsky, A.D., 1912. Verkhnemelovyye otlozheniya vostoka evropeyskoy Rossii (in Russian). Materialy dla Geologii Rossii, 25: 1-631.

Arthur, M.A., Fisher, A.G., 1977. Upper Cretaceous-Paleocene Magnetic Stratigraphy at Gubbio, Italy. I. Lithostratigraphy and sedimentology. GSA Bulletin, 88: 367-371.

Besse, J., Courtillot, V., 2003. Correction to apparent true polar wander and the geometry of the geomagnetic field over the last 200 Mys. Journal of Geophysical Research, 108 (B10): EPM 3 $(1-2)$.

Birkelund, T., Hancock, J.M., Hart, M.B., Rawson, P.F., Remane, J., Robaszynski, F., Schmid, F., Surlyk, F., 1984. Cretaceous stage boundaries - proposals. Bulletin of the Geological Society of Denmark, 33: 3-20.

Błaszkiewicz, A., 1980. Campanian and Maastrichtian ammonites of the Middle Vistula River valley, Poland: a stratigraphic and paleontological study. Prace Instytutu Geologicznego, 92: 1-63.

Burnett, J.A., 1998. Upper Cretaceous. In: Calcareous Nannofossil Biostratigraphy (ed. P.R. Blown): 132-199. Chapman \& Hall, London.

Burnett, J.A., Hancock, J.M., Kennedy, W.J., Lord, A.R., 1992 Macrofossil, planktonic foraminiferal and nannofossil zonations at the Campanian/Maastrichtian boundary. Newsletters on Stratigraphy, 27: 157-172.

Chadima, M., Hrouda, F., 2006. Remasoft 3.0 a user-friendly paleomagnetic data browser and analyzer. Travaux Géophysiques, 27: 20-21.

Christensen, W.K., Hancock, J.M., Peake, N.B., Kennedy, W.J., 2000. The base of the Maastrichtian. Bulletin of the Geological Society of Denmark, $47: 81-85$.

Coccioni, R., Premoli Silva, I., 2015. Revised Upper AlbianMaastrichian planktonic foraminiferal biostratigraphy and magnetostratigraphy of the classical Tethuan Gubbio section (Italy). Newsletters on Stratigraphy, 48: 47-90.

Dubicka, Z., Peryt, D., 2012. Latest Campanian and Maastrichtian palaeoenvironmental changes: implications from an epicontinental sea (SE Poland and western Ukraine). Cretaceous Research, 37: 272-284.

Dunlop, D.J., Özdemir, Ö., 1997. Rock Magnetism. Fundamentals and Frontiers. Cambridge Studies in Magnetism Series. Cambridge University Press, Cambridge, New York, Port Chester, Melbourne, Sydney.
Gaździcka, E., 1978. Calcareous nannoplankton from the uppermost Cretaceous and Palaeogene deposits of the Lublin Upland. Acta Geologica Polonica, 23: 335-375.

Gill, J.R., Cobban, W.A., 1966. The Red Bird section of the Upper Cretaceous Pierre Shale in Wyoming. United States Geological Survey, Professional Paper, 393A: 1-73.

Hambach, U., Hiss, M., Peryt, D., 1995. Magnetostratigraphy of Santonian to Maastrichtian strata from NW Germany and Poland. 2nd International Symposium on Cretaceous Stage Boundaries, Brussels, 1995, Abstract Volume: 51.

Hansen, H.J., Rasmussen, K.L., Gwozdz, R., Hansen, J.M., Radwański, A., 1989. The Cretaceous/Tertiary boundary in Central Poland. Acta Geologica Polonica, 39: 1-12.

Hicks, J.F, Obradovich, J.D., 1995. A new calibration point for the Late Cretaceous time scale: The ${ }^{40} \mathrm{Ar} /{ }^{39} \mathrm{Ar}$ isotopic age of the C33r/C33n geomagnetic reversal from the Judith River Formation (Upper Cretaceous), Elk Basin, Wyoming, USA. The Journal of Geology, 103: 243-256.

Howe, R.W., Campbell, R.J., Rexilius, J.P., 2003. Integrated uppermost Campanian-Maastrichtian calcalerous nannofossil and foraminiferal biostratigraphic zonation of the northwestern margin of Australia. Journal of Micropalaeontology, 22: 29-62.

Jeletzky, J.A., 1951. Die Stratigraphie und Belemnitenfauna des Obercampan und Maastricht Westfalens, Nordwestdeutschlands und Dänemarks, sowie einige allgemeine Gliederungs-Probleme der jüngeren borealen Oberkreide Eurasiens. Beihefte Geologisches Jahrbuch, 1: 1-142.

Keutgen, N., Remin, Z., Walaszczyk, I., 2012. Early representatives of the belemnite genus Belemnella (Cephalopoda) from the uppermost Campanian-Lower Maastrichtian of the Middle Vistula River section, central Poland. Acta Geologica Polonica, 62: 535-559.

Kirschvink, J.L., 1980. The least-squares line and plane and the analyses of paleomagnetic data. Geophysical Journal of the Royal Astronomical Society, 62: 699-718.

Kongiel, R., 1962. On belemnites from Maastrichtian, Campanian and Santonian sediments in the Middle Vistula valley (Central Poland). Prace Muzeum Ziemi, 5: 3-148.

Kutek, J., 2001. The Polish Permo-Mesozoic Rift Basin. Mémoires du Muséum National d'Histoire Naturelle, 186: 213-236.

Lerbekmo, J.F., Braman, D.R., 2002. Magnetostratigraphic and biostratigraphic correlation of late Campanian and Maastrichtian marine and continental strata from the Red Deer Valley to the Cypress Hills, Alberta, Canda. Canadian Journal of Earth Sciences, 39: 539557.

Lewandowski, M., Werner, T., Nowożyński, K., 1997. PCA - a package of Fortran programs for palaeomagnetic data analysis. 
Institute of Geophysics, Polish Academy of Sciences. [unpublished manuscript]

Lowrie, W., 1990. Identification of ferromagnetic minerals in a rock by coercivity and unblocking temperature properties. Geophysical Research Letters, 2: 159-162.

Lowrie, W., Alvarez, W., 1981. 100 million years of geomagnetic polarity history. Geology, 9: 392-397.

Machalski, M., 1996. Scaphitid ammonite correlation of the late Maastrichtian deposits in Poland and Denmark. Acta Palaeontologica Polonica, 41: 369-383.

Machalski, M., 2012. Stratigraphically important ammonites from the Campanian-Maastrichtian boundary interval of the Middle Vistula River section, central Poland. Acta Geologica Polonica, 62: 91-116.

McFadden, P.L., McElhinny, M.W., 1990. Classification of the reversal test in palaeomagnetism. Geophysical Journal International, 103: 725-729.

Mutterlose, J., Bornemann, A., Herrle, J.O., 2005. Mesozoic calcareous nannofossils - state of the art. Paläontologische Zeitschrift, 79: 113-133.

Odin, G.S. (compiler), 1996. Definition of a Global Boundary Stratotype Section and Point for the Campanian and Maastrichtian boundary. Bulletin de l'Institut Royal des Sciences Naturelles de Belgique, Sciences de la Terre, 66: $111-117$.

Odin, G.S., Lamaurelle, M.A., 2001. The global Campanian-Maastrichtian stage boundary. Episodes, 24: 229-238.

Ogg, J.G., Hinnov, L.A., 2012. Chapter 27, Cretaceous. In: The Geologic Time Scale 2012 (eds. F. Gradstein, J. Ogg, M. Schmitz and G. Ogg): 793-853. Oxford, Elsevier.

Peryt, D., 1980. Planktic foraminifera zonation of the Upper Cretaceous in the Middle Vistula River Valley, Poland. Palaeontologia Polonica, 41: 3-101.

Peryt, D., 2000. On the age of siliceous chalk in the Piotrawin quarry, Middle Vistula River valley, Central Poland (in Polish with English summary). Biuletyn Państwowego Instytutu Geologicznego, 393: 81-94.

Peryt, D., Dubicka, Z., 2015. Foraminiferal bioevents in the Upper Campanian to lowest Maastrichtian of the Middle Vistula River section, Poland. Geological Quarterly, 59 (4): 814-830.

Pożaryska, K., 1954. The Upper Cretaceous index Foraminifera from Central Poland (in Polish with English summary). Acta Geologica Polonica, 4: 249-276.

Pożaryska, K., Peryt, D., 1979. The Late Cretaceous and Early Paleocene foraminiferal "Transitional Province" in Poland. IUGS Series, A6: 293-303.

Pożaryski, W., 1938. Senonstratigraphie im Durchbruch der Weichsel zwischen Rachów und Puławy in Mittelpolen (in Polish with German summary). Biuletyn Państwowego Instytutu Geologicznego, 6: 3-94.

Pożaryski, W., 1948. Jurassic and Cretaceous between Radom, Zawichost and Kraśnik (Central Poland) (in Polish with English summary). Biuletyn Państwowego Instytutu Geologicznego, 46: $1-141$.
Pożaryski, W., 1974. Tektonika, cz. 1. Niż Polski (in Polish). In: Budowa geologiczna Polski (ed. W. Pożaryski): 2-34. Wyd. Geol., Warszawa.

Remin, Z., 2012. The Belemnella stratigraphy of the Campanian-Maastrichtian boundary: a new methodological and taxonomic approach. Acta Geologica Polonica, 62: 495-533.

Remin, Z., 2015. The Belemnitella stratigraphy of the Upper Campanian-basal Maastrichtian of the Middle Vistula section, central Poland. Geological Quarterly, 59 (4): 783-813.

Remin, Z., Machalski, Z., Jagt, W.M. 2015. The stratigraphically earliest record of Diplomoceras cylindraceum (heteromorphy ammonite) - implications for Campanian-Maastrichtian boundary definition. Geological Quarterly, 59 (4): 843-848.

Świerczewska-Gładysz, E., 2006. Late Cretaceous siliceous sponges from the Middle Vistula River Valley (Central Poland) and their palaeoecological significance. Annales Societatis Geologorum Poloniae, 76: 227-296.

Świerczewska-Gładysz, E., 2012. Hexactinellid sponge assemblages across the Campanian-Maastrichtian boundary in the Middle Vistula River section, central Poland. Acta Geologica Polonica, 62: 561-580.

Voigt, S., Gale, A.S., Jung, C., Jenkyns, H.C., 2012. Global correlation of Upper Campanian Maastrichtian successions using carbon-isotope stratigraphy: development of a new Maastrichtian timescale. Newsletters on Stratigraphy, 45: 25-53.

Walaszczyk, I., 2004. Inoceramids and inoceramid biostratigraphy of the Upper Campanian to basal Maastrichtian of the Middle Vistula River section, central Poland. Acta Geologica Polonica, 54: 95-168.

Walaszczyk, I., 2012. Integrated stratigraphy of the Campanian-Maastrichtian boundary succession of the Middle Vistula River (central Poland) section; introduction. Acta Geologica Polonica, 62: 485-493.

Walaszczyk, I., Cobban, W.A., Harries, P.J. 2001. Inoceramids and inoceramid biostratigraphy of the Campanian and Maastrichtian of the United States Western Interior Basin. Revue de Paléobiologie, 20: 117-234.

Walaszczyk, I., Odin, G.S., Dhondt, A.V., 2002a. Inoceramids from the Upper Campanian and Lower Maastrichtian of the Tercis section (SW France), the Global Stratotype Section and Point for the Campanian-Maastrichtian boundary; taxonomy, biostratigraphy and correlation potential. Acta Geologica Polonica, 52: 269-305.

Walaszczyk, I., Cobban, W.A., Odin, G.S., 2002b. The inoceramid succession across the Campanian-Maastrichtian boundary. Bulletin of the Geological Society of Denmark, 49: 53-60.

Ward, P.D., Haggart, J.W., Mitchell, R., Kirschvink, J.L., Tobin, T., 2012. Integration of macrofossil biostratigraphy and magnetostratigraphy for the Pacific Coast Upper Cretaceous (Campanian-Maastrichtian) of North America and implications for correlation with the Western Interior and Tethys. GSA Bulletin, 124: 957-974.

Żelaźniewicz, A., Aleksandrowski, P., Buła, Z., Karnowski, P.H., Konon, A., Oszczypko, N., Ślączka, A., Żaba, J., Żytko, K., 2011. Regionalizacja Tektoniczna Polski (in Polish). Komitet Nauk Geologicznych PAN, Wrocław. 